\title{
The Influence of Teaching Approaches among Technical and Vocational Education Teachers towards Acquisition of Entrepreneurship Skills in Kano State-Nigeria
}

\author{
Ali Idris ${ }^{1}$ Muhammad Rashid Rajuddin ${ }^{2}$ \\ ${ }^{1}$ (Department of Technical and Engineering Education, Universiti Teknologi Malaysia) \\ ${ }_{2}^{2}$ (Department of Science and Technology Education, Bayero University Kano-Nigeria)
}

\begin{abstract}
The study examine the influence of teaching approaches towards the teaching of entrepreneurship skills in technical and vocational schools in Kano State of Nigeria. Two hundred and twenty (220) technical teachers in post-primary schools were used as the respondents for the study. The teaching methods employed for this study were: Problem Based Method, Context Based Method, Student Centred Method, Demonstration Method, Project Based Method, Lecture Method, Tutorial and Seminars, Fieldwork and Computer Based Method. The findings revealed that, Problem based method, context based, students centred, demonstration and computer based teaching methods were significant predictors of entrepreneurship skills among students of technical schools.
\end{abstract}

Keywords: Entrepreneurship Skills, Teaching Approaches, Technical and Vocational Education.

\section{Introduction}

Technical and vocational education is 'used as a comprehensive term referring to those aspects of the educational process involving, in addition to general education, the study of technologies and related sciences, and the acquisition of practical skills, attitudes, understanding and knowledge relating to occupations in various sectors of economic and social life' (UNESCO, 2001,[1]). It is the type of education that gives training to individuals to acquire knowledge and skills for employment in different occupational disciplines; the training is categorized in to a semi-skilled, technician or sub-professional. It is the type of education that provides individuals with practical skills and knowledge for the preparation of employment as employee or to become self-reliant and become employer. Technical and vocational education system in Nigeria is designed to produce competent craftsmen for the different sector of the economy who are expected after graduation to be able to test, diagnose, service and carryout repairs as specified in the national curriculum which was adopted by all technical colleges across the country and accredited by National Board for Technical Education (Olayinka and Oyenuga, 2010, [2]).

The national policy on education states that, the trainees completing technical college programs shall have the option of securing employment at the end of the whole course or after completing one or two modules of employable skills or set up their own business and become self-employed and be able to employ others (NPE, 2004). Training of youths through entrepreneurship education can be regarded as another way of creating employment, particularly for the graduates of technical and vocational education training schools who are bedeviled with the problem of mismatch and have also the opportunity of having different options if they are given the appropriate training and education. However, in most of the African countries, Nigeria inclusive has introduced entrepreneurship education as part of the national curricula for technical and vocational education programs. The main aim of the integration of entrepreneurship is to create business and self-employment attitudes among the youths of technical and vocational education in order to have a career option after graduation (Haan, 2006,[4]).

Dar-Chin, Shao-Tsu \& Ming-Hua (2006,[5]) explained that, technical and vocational education could help students develop their business abilities through learning; therefore, the teaching approaches in technical and vocational subjects should give more emphasis on the inspiration and flexibility, adaptability and future needs of businesses. These are also three guidelines to be considered in helping the students to learn:

\section{i. Inspire students' creativity through flexible teaching.}

Teachers play a very important role in aiding students to develop creative and critical thinking through their teaching approaches which are both complementary to each other. The approach should be flexible in nature so as to allow students to work and think on their own in order to come up with ideas through creativity and critical thinking. This will also make the student proud to any new discovery made by themselves and will inspire them in the future. 


\section{ii. Adaptive teaching and adaptive development.}

Interests, abilities, and aptitudes varies among students on different phenomenon, therefore, the teaching approach should encourage students to develop their potentials according to their own phase and also to learn among their group members or mates.

\section{iii. Competence-based teaching to develop abilities that meet business needs.}

The modern day business is full of challenges, innovative and competiveness for a business to survive. In order to succeed in the business world of today, teachers must help in developing their students towards business orientation for future need. Students with different talents and working as team will guarantee a success in business venture.

\section{Entrepreneurship}

Entrepreneurship education focuses on developing understanding and capacity for pursuit of entrepreneurial behaviors, skills and attributes in widely different contexts. It can be portrayed as open to all and not exclusively the domain of the high-flying growth-seeking business person. The propensity to behave entrepreneurially is not exclusive to certain individuals. Different individuals will have a different mix of capabilities for demonstrating and acquiring entrepreneurial behaviors, skills and attributes. These behaviors can be practiced, developed and learned; hence it is important to expose all students to entrepreneurship education. Meanwhile globalization, the rapid development of technology and the lower cost of travel have completely changed the nature of work. It is no longer enough to train students for a career. Universities must prepare students to work in a dynamic, rapidly changing entrepreneurial and global environment. In the United States, entrepreneurship has historically been a key driver of economic growth. In the past several decades, entrepreneurial dynamism has been evident both in the number of new enterprises created each year and in the fact that, of the leading 100 United States firms, the majority did not exist 20-30 years ago.

\subsubsection{Research Objectives}

The main objective of this research is as to examine the influence teaching approaches towards entrepreneurship skills by the teachers on technical and vocational education students.

\subsubsection{Research Questions}

Do the teaching approaches influence entrepreneurship skills among students?

\subsection{Research Methodology}

A survey research was conducted in Kano State of Nigeria on all the trade teachers in technical colleges as well as some technical teachers of secondary schools. Two hundred and twenty (220) teachers were used as the sample of the study from various technical fields. Five likert scale questionnaire was adapted by the researcher that was duly validated in terms of content by four experts. The result of reliability coefficient was sought using Cronbach's Alpha which yielded the value of 0.944 . The instrument consisted of 51 items on a five point scale of Very High Importance (5), High Importance (4), Moderate Importance (3), Low Importance (2) and Very Low Importance (1). In analyzing the results of the study, independent t-test and regression analysis was conducted using SPSS version 17.0.

\subsection{Results and Discussions}

Entrepreneurship skills that are basically needed for business and other enterprises, the national policy have indicated the need for the students to acquire such skills before graduation which could help them to open up their businesses. To this end, the result of this study shows different types of teaching methods to be considered in the teaching of entrepreneurship in Nigeria. 


\begin{tabular}{|c|c|c|c|c|c|c|c|}
\hline Variable & & EB & $\square$ & & 2 & justed $R^{2^{2 d}}$ & \\
\hline Problem based method & 143 & 033 & 260 & .339 & 543 & 3.52 & 000 \\
\hline Method Context based & 166 & 035 & 284 & .739 & 543 & .52 & 000 \\
\hline $\begin{array}{l}\text { Student } \\
\text { centred method }\end{array}$ & 081 & 038 & 132 & .133 & 543 & .52 & 034 \\
\hline $\begin{array}{l}\text { Demonstratio } \\
\mathrm{n} \text { method }\end{array}$ & 108 & 038 & 179 & .867 & 543 & .52 & 005 \\
\hline $\begin{array}{l}\text { Project Based } \\
\text { Method }\end{array}$ & 004 & 036 & 008 & 097 & 543 & .52 & 923 \\
\hline $\begin{array}{l}\text { Lecture } \\
\text { method }\end{array}$ & .021 & 030 & .052 & .703 & 543 & .52 & 483 \\
\hline $\begin{array}{l}\text { Tutorial and } \\
\text { seminars }\end{array}$ & .041 & 030 & .114 & 1.363 & 543 & 3 & 175 \\
\hline Fieldwork & 037 & 042 & 068 & 879 & 543 & .52 & 380 \\
\hline $\begin{array}{l}\text { Computer } \\
\text { Based Method }\end{array}$ & oso & 032 & 202 & .549 & 543 & .52 & 012 \\
\hline
\end{tabular}

Table 1 reveals a significant model for the predictors of entrepreneurship skills among the teaching methods with a multiple regression coefficient of .73, $\left[\mathrm{F}(9,208)=27.452\right.$, $\mathrm{P}<.05$; adjusted $\left.\mathrm{R}^{2}=.543\right]$. However, the table shows that problem based, context based, Student centred, demonstration and computer based teaching methods were significant predictors for entrepreneurship skills among students.

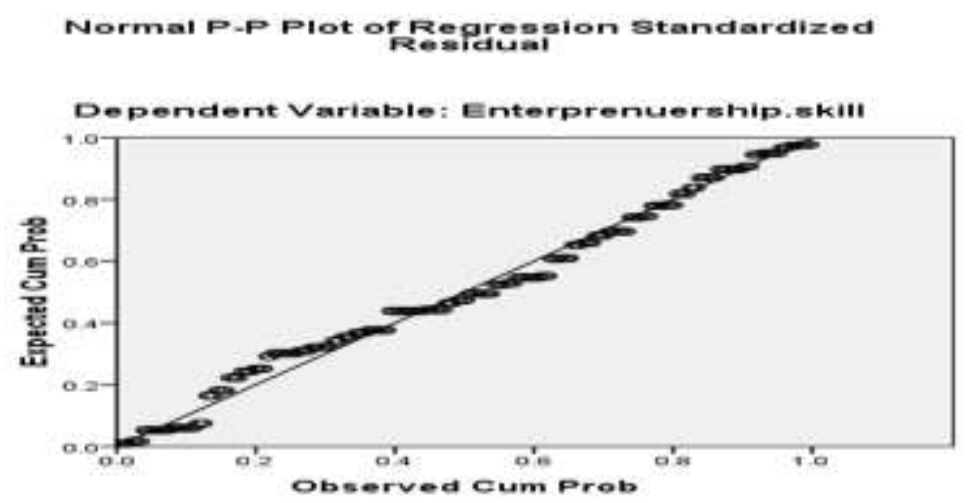

Figure 1: Normal P-P Plot of Regression Standardized Residual on Entrepreneurship Skills

The graph indicates the normal distribution of the data. The graph depicts that there is fairly normal distribution as the dots lie very close to the diagonals. The diagram in figure 1 shows a very strong correlation between entrepreneurship skills and teaching methods, therefore this indicates that one of the requirements has been satisfied.

The findings on teaching approaches towards entrepreneurship skills presented in Table 1 shows that, for teachers to effectively impart the knowledge of business enterprise to the students in order to be self-reliant and start-up their business as well as employ others, they need to have full knowledge of business skills, therefore, the results shows that teachers need to employ Problem based method, context based, students centred, demonstration and computer based methods for their teaching in order to effectively equip the students with such skills. However, the training of students to acquire the knowledge and skills in terms entrepreneurship and set-up their business after graduation is part of the goals of the current National Policy on Education $(2004,[3])$ in Nigeria, therefore, entrepreneurship skills is an important area in technical and vocational education in the country.

In support of this result, Olajide and James $(2011,[6])$ believed that, problem-based teaching method helps in developing the learner to be a good entrepreneur, the teaching approach should be able to expose the learner to ask questions, observe and make reasonable explanations, be able to investigate, to develop scientific methods and attitudes, and be able to share knowledge and information. These could be achieved through the application of knowledge and effective communication, the learner should also be curious, imaginative, analytical in various problems, critical thinker and also self-confident. The inquiry teaching method focuses on more on problem solving activity with less emphasis on traditional teaching method. 


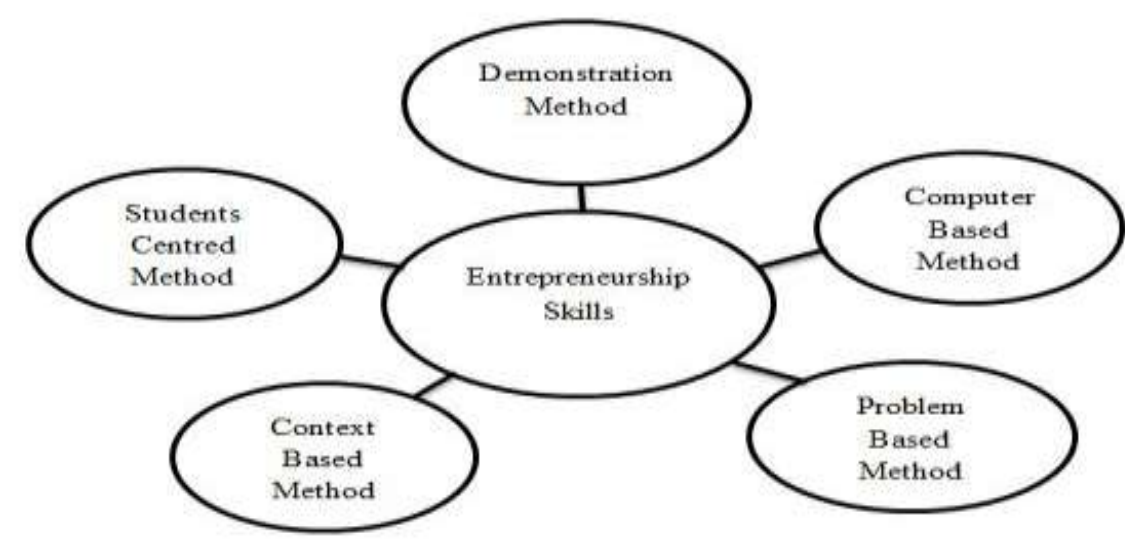

Figure 2: Teaching Approaches towards Entrepreneurship Skills

In a related study, Vaidya (2007,[7]) reported that, the major thrust of his study is to let the learners to gain practical base towards learning a specific knowledge in order to explore how learners understand entrepreneurship. The experiment contains lesson notes and narrative as well as teaching materials that were designed to avail the learner to have the opportunity of promoting entrepreneurial vision, entrepreneurship skills and initiative under the school education guidance. Imperatively, the results signify that each learner has equal opportunity to be become an entrepreneur using adequate and proper teaching method. Consequently, in a study conducted by Akpomi $(2009,[8])$ found that, the present process of education in Nigeria in terms of teaching method is too mechanistic that focused only on lecture method which eventually does not promote entrepreneurial behavior among the students as well as self-enterprise. This has posed a challenge to technical and vocational education teachers towards training students that will be self-reliant after graduation. In the United States for example, entrepreneurship education is closely attached to business practices in which teachers have experience working with entrepreneurs. Therefore, the courses offered are structured in such a way that students are exposed to real life cases, internships, competitions on business plans, projects etc. These are achieved through the involvement of expertise specifically the entrepreneurs to come to class and deliver lessons on entrepreneurship which serves as a role model for students to develop interest in entrepreneurial career (Wilson, 2008,[9]).

\section{Conclusion}

The national policy on education emphasizes on the training of students of technical and vocational schools in the country in order to develop their skills for them to be self-employed. Therefore, training at this stage of post-primary education should be given a priority so as to enhance skills for the labor force through lifelong learning in order to update and retool the needed skills by the students. Government should provide more resources towards teaching entrepreneurship in technical and vocational schools. There should also be training and re-training of teachers through seminars and workshops in order to equip them with necessary teaching methods towards delivering entrepreneurship skills among the students. Teachers should use practical approach to enhance the delivery of their teaching and impart the necessary skills needed for self-employment by collaborating with entrepreneurs within their localities.

\section{References}

[1] UNESCO (2001). Technical and Vocational Education for Twenty-First Century. Annex of the Revised Recommendation concerning Technical and Vocational Education. 5-51

[2] Olayinka, O. and Oyenuga, O.A. (2010). Integration of Automobile Technological Developments into Nigeria Technical College Motor Mechanics Work Curriculum. Academic Leadership: The Online Journal, 8(2), 1-11.

[3] National Policy of Education (2004). Federal Republic of Nigeria. Lagos: NERDC Press.

[4] Haan, H.C. (2006). Training for work in the informal micro-enterprise sector: Fresh evidence from sub-Sahara Africa : Dordrecht, The Netherlands, Springer.

[5] Dar-Chin, R., Shao-Tsu., Ping, L.and Ming-Hua (2006). Development and Teaching Approaches of Technical and Vocational Education Curricula. 9th International Conference on Engineering Education.23 - 28 July. San Juan, PR.

[6] Olajide, J.O., and James, T. (2011). The Role of Inquiry Teaching in Promoting Entrepreneurship at the Primary and Secondary School Levels in Nigeria. Int J Edu Sci, 3(2): 75-78 (2011).

[7] Vaidya, S. (2007). Developing Entrepreneurial Life Skills: An Experiment in Indian Schools. Institute for Small Business \& Entrepreneurship. Available at: www.isbe.org.uk/content/assets/BP07-New.pdf.

[8] Akpomi, E.M. (2009). Achieving Millennium Development Goals (MDGs) Through Teaching Entrpreneurship Education in Nigeria Higher Education Institutions (HEIs), European Journal of Social Sciences, 8(1),152-157.

[9] Wilson, K. (2008). Entrepreneurship and Higher education. Entrepreneurship Education in Europe. European Foundation for Entrepreneurship Research, P1-9. 